\title{
Deep back dan rubbing massage berpengaruh terhadap penurunan intensitas nyeri dan percepatan pembukaan serviks ibu bersalin
}

\author{
Enny Fitriahadi ${ }^{1} *$, Istri Utami ${ }^{2}$ \\ ${ }^{1,2}$ Program Studi Kebidanan Program Sarjana Terapan, Universitas 'Aisyiyah Yogyakarta-Indonesia
}

\begin{abstract}
The purpose of this study was to determine the effect of deep back and rubbing massage on the decrease in the intensity of labor pain and the acceleration of cervical opening in labor. The sample in this study were 40 samples, 20 intervention groups and 20 control groups. This research method will use a quantitative design with quasy experimental design with a non-randomized pretest-posttes group design. Different test results of pre-test and post-test in the experimental or non-experimental group using T-test analysis were used to determine differences in pre-test and post-test in 2 different groups, namely the intervention group and the control group. The results of this study obtained sig. less than 0.05 ( $p=0.000<0.05$ ), so it can be stated that there is a significant difference in the decrease in pain intensity and cervical opening in the experimental group. Suggestions for pregnant women are expected to be able to do deep back and rubbing massage done by husband or midwife so that the intensity of pain during the first stage of labor can be reduced and the cervical opening is increasing.
\end{abstract}
Keywords: deep back and rubbing massage; pain intensity and acceleration of cervical opening

\begin{abstract}
Tujuan dari penelitian adalah mengetahui pengaruh deep back dan rubbing massage terhadap penurunan intensitas nyeri persalinan dan percepatan pembukaan serviks pada ibu bersalin. Sampel dalam penelitian ada 40 sampel, 20 kelompok intervensi dan 20 kelompok kontrol. Metode penelitian ini akan menggunakan rancangan kuantitatif dengan quasy experimental design dengan desain nonrandomized pretest-posttes group. Uji beda hasil pre test dan post test pada kelompok eksperimen atau non eksperimen menggunakan analisis $T$ test digunakan untuk mengetahui perbedaan pre test dan post test pada 2 kelompok yang berbeda yaitu kelompok intervensi dan kelompok kontrol. Hasil penelitian ini didapatkan nilai sig. kurang dari $0,05(p=0,000<0,05)$, sehingga dapat dinyatakan terdapat perbedaan yang signifikan dalam penurunan intensitas nyeri dan pembukaan serviks pada kelompok eksperimen. Saran bagi Ibu hamil diharapkan dapat melakukan deep back dan rubbing massage yang dilakukan oleh suami atau bidan sehingga intensitas nyeri saat persalinan kala I dapat berkurang dan pembukaan serviks semakin bertambah.
\end{abstract}

Kata Kunci: deep back dan rubbing massage; intensitas nyeri dan percepatan pembukaan serviks

\footnotetext{
*Corresponding Author: Enny Fitriahadi (email ennyfitriahadi@rocketmail.com)
} 


\section{PENDAHULUAN}

Persalinan merupakan proses membuka dan menipisnya serviks dan janin turun kedalam jalan lahir kemudian berakhir dengan pengeluaran bayi yang cukup bulan atau hampir cukup bulan atau dapat hidup diluar kandungan disusul dengan pengeluaran placenta dan selaput janin dari tubuh ibu melalui jalan lahir, atau jalan lahir dengan bantuan, atau tanpa bantuan (kekuatan sendiri). Persalinan dianggap normal jika prosesnya terjadi pada usia kehamilan cukup bulan (setelah 37 minggu) tanpa disertai adanya penyulit (Marmi, 2012).

Menurut Lestari (2012), dalam penelitiannya terhadap 2.700 parturien di 121 pusat obstetrik dari 36 negara menemukan bahwa hanya $15 \%$ persalinan yang berlangsung tanpa nyeri atau nyeri ringan, $35 \%$ persalinan disertai nyeri sedang, 30\% persalinan disertai nyeri hebat dan $20 \%$ persalinan disertai nyeri yang sangat hebat (Lestari, 2012).

Nyeri persalinan mulai timbul pada tahap kala I yang berasal dari kontraksi uterus dan dilatasi serviks. Dengan makin bertambahnya baik lama maupun frekuensi kontraksi uterus, nyeri yang dirasakan akan bertambah kuat (Lestari, 2012). Association for the study of pain dalam Judha 2012, menya- takan nyeri merupakan pengalaman emosional dan sensori yang tidak menyanangkan yang muncul dari kerusakan jaringan secara aktual atau potensial atau menunjukkan adanya kerusakan (Judha, 2012) .

Nyeri persalinan dapat menimbulkan kecemasan serta ketakutan pada pasien sehingga kebutuhan oksigen meningkat, otot menjadi tegang serta tekanan darah meningkat, keadaan ini akan merangsang katekolamin yang dapat menyebabkan terjadinya pada kekuatan kontraksi sehingga mengakibatkan partus lama (Anggraeni, 2015). Penanganan dan pengawasan nyeri persalinan terutama pada kala I fase aktif sangat penting, karena ini sebagai titik penentu apakah seorang ibu bersalin dapat menjalani persalinan normal atau diakhiri suatu tindakan dikarenakan adanya penyulit yang diakibatkan nyeri yang sangat hebat. Mengingat dampak nyeri cukup signifikan bagi ibu dan bayi, maka harus ada upaya untuk menurunkan nyeri tersebut (Maita., 2016).

Metode yang digunakan untuk menurunkan nyeri persalinan dapat dilakukan secara farmakologi dan non farmakologi. Teknik pijatan yang dapat dilakukan dengan deep back massage dan rubbing massage. Dalam hal ini perlu kiranya diteliti perbedaan an- 
tara deep back dan rubbing massage yang kemudian dapat ditawarkan kepada ibu. Berdasarkan uraian diatas penulis tertarik melakukan penelitian yang bertujuan menganalisa perbedaan metode deep back dan rubbing massage dengan penurunan intensitas nyeri dan percepatan pembukaan serviks pada ibu bersalin (Lestari, 2012).

Menurut penelitian Aryani (2015) bahwa Massage yang dilakukan sebagai proses pengurangan rasa nyeri dengan melakukan penekanan pada daerah sacrum 2,3,4 pada saat ada kontraksi selama 20 menit, sekitar 6-8 kali penekanan dengan menggunakan telapak tangan bagian bawah, dengan kekuatan tekanan bertumpu pada pangkal lengan. Dilakukan tiga kali siklus pada fase aktif kala I persalinan dengan pembukaan 4-7 cm (Aryani, et al., 2015).

Menurut penelitian Gaidaka (2017) dengan judul pengaruh deep backmassage terhadap nyeri persalinan kala I fase aktif ibu inpartu primigravida, menyatakan bahwa ada pengaruh deep back massage terhadap nyeri persalinan kala I fase aktif ibu inpartu primigravida. Pemberian deep back massage yang tepat dan sering, yang dilakukan oleh pendamping persalinan maupun keluarga akan mengurangi nyeri persalinan kala I fase aktif (Gaidaka., 2017).

Menurut penelitian Fitrianingsih (2017) menemukan bahwa Nyeri paling dominan dirasakan pada saat persalinan terutama selama kala I fase aktif. Nyeri persalinan dapat menimbulkan stres yang menyebabkan pelepasan hormon yang berlebihan seperti katekolamin dan steroid. Sekresi hormon tersebut yang berlebihan akan menimbulkan gangguan sirkulasi uteroplasenta sehingga terjadi hipoksia janin. Salah satu untuk mengendalikan nyeri persalinan dengan metode nonfarmakologi yaitu dengan metode deep back massage dan metode endorphine massage (Fitrianingsih., 2017).

Nyeri pada persalinan umumnya terasa hebat, hanya $2-4 \%$ ibu saja yang mengalami nyeri ringan selama persalinan. Ketakutan ibu hamil akan nyeri persalinan atau ketidakmampuan ibu hamil untuk menahan dan menerima nyeri persalinan saat persalinan yang dilaluinya akan berdampak terhadap penurunan keberhasilan persalinan normal. Teknik alami untuk meredakan nyeri salah satunya dengan melakukan Deep Back Massage dan Counter pressure Massage (Susanti., 2019).

Berdasarkan penilitian Suriani (2019) dengan judul Pengaruh Teknik Massage Back- 
Effleurage Terhadap Pengurangan Rasa Nyeri Persalinan Kala I Di Klinik Bersalin Kurnia Kecamatan Delitua Kabupaten Deli Serdang.। menyatakan bahwa ada pengaruh yang signifikan antara Teknik Massage Back-Effleurage terhadap pengurangan rasa nyeri persalinan Kala I (Suriani., 2019).

Kebaharuan dari penelitian ini adalah berdasarkan sepengetahuan penelitian kombinasi intervensi deep back dan rubbing massage terhadap penurunan intensitas nyeri dan percepatan pembukaan serviks ibu bersalin belum pernah diteliti.

Model rancangannya adalah :

Pre test Intervensi Post test

Eksperimen

Kontrol01'

Xa

Pembentukan kelompok dengan cara membagi dua, kelompok satu sebagai kelompok yang diberikan intervensi dengan melakukan perlakuan deep back dan rubbing massage dan kelompok kedua sebagai kelompok non intervensi yang tidak diberikan perlakuan.

\section{METODE}

Penelitian ini adalah quasi eksperimen (quasi experimental) dan mengukur pengaruh deep back dan rubbing massage terhadap penurunan intensitas nyeri dan percepatan pembukaan serviks pada ibu bersalin. Penelitian ini membandingkan antara kelompok yang diberikan perlakuan (kelompok intervensi) dengan yang tidak diberikan perlakuan (kelompok non intervensi). Design yang digunakan adalah non-randomized pretestposttes group (Subaris, 2012).

$\mathrm{X}$

02 
intervensi peneliti akan melakukan pre test tanpa diberikan perlakuan dan pada waktu yang berbeda akan mengadakan post test, setelah post test dilakukan maka akan diberikan deep back dan rubbing massage.

Populasi dalam penelitian ini adalah semua ibu bersalin di BPM Kabupaten Sleman. Populasi dalam penelitian ini bersifat homogen yaitu memiliki karakteristik yang sama yaitu 40 ibu bersalin. Jumlah sampel dalam penelitian 40 responden dengan pembagian 20 responden pada kelompok eksperimen dan 20 pada kelompok non eksperimen. Teknik pengambilan sampel adalah total
Uji statistik yang akan digunakan untuk mengetahui perbedaan hasil pre test dan post test pada kelompok eksperimen/non eksperimen menggunkan Wilcoxon dan untuk mengetahui perbedaan pre test dan post test pada 2 kelompok yang berbeda metode yang digunakan adalah $T$ test (Dahlan, 2013).

\section{HASIL DAN PEMBAHASAN}

Analisis univariat dilakukan untuk melihat rata - rata dari nilai intensitas nyeri dan pembukaan serviks pada ibu bersalin dari tiap kelompok. Hasil perhitungan diperoleh sebagai berikut: sampling.

Tabel 1. Hasil Nilai Rata - rata dari Nilai Intensitas Nyeri dan Pembukaan Servik

\begin{tabular}{|c|c|}
\hline Rata - rata intensitas nyeri (pre) & Rata - rata intensitas nyeri (post) \\
\hline 3.9500 & 2.7500 \\
\hline Rata - rata pembukaan serviks (pre) & Rata - rata pembukaan serviks (post) \\
\hline 6.9000 & 9.0500 \\
\hline \multicolumn{2}{|l|}{ a. Kelompok eksperimen } \\
\hline Rata - rata intensitas nyeri (pre) & Rata - rata intensitas nyeri (post) \\
\hline 4.4000 & 2.7000 \\
\hline Rata - rata pembukaan serviks (pre) & Rata - rata pembukaan serviks (post) \\
\hline 6.8000 & 9.1000 \\
\hline \multicolumn{2}{|l|}{ b. Rata - rata selisih pre dan post } \\
\hline $\begin{array}{l}\text { Rata - rata selisih intensitas } \\
\text { nyeri (kelompok kontrol) }\end{array}$ & $\begin{array}{l}\text { Rata - rata selisih intensitas nyeri (kelompok } \\
\text { perlakuan) }\end{array}$ \\
\hline 1.45000 & 0.14 \\
\hline \multicolumn{2}{|l|}{$\begin{array}{l}\text { Rata - rata selisih pembukaan } \\
\text { serviks (kelompok kontrol) }\end{array}$} \\
\hline
\end{tabular}

2.22500

Intensitas nyeri dan pembukaan serviks sebelum diberikan intervensi deep back dan rubbing massage
0.14

Intensitas nyeri pada kelompok eksperimen sebelum dilakukan intervensi adalah 3.9500 sedangkan pada kelompok kontrol 4.4000. Pembukaan serviks pada kelompok 
eksperimen sebelum dilakukan intervensi adalah 6.9000 sedangkan pada kelompok kontrol 6.8000 .

Nyeri persalinan adalah kondisi fisiologis yang secara umum akan dialami oleh hampir semuaibu bersalin. Rasa nyeri adalah manifestasi dari adanya kontraksi otot rahim. Kontraksi inilahyang menimbulkan rasa sakit pada pinggang, daerah perut dan menjalar kearah paha. Kontraksiini menyebabkan adanya pembukaan mulut rahim (serviks). Dengan adanya pembukaan serviksinilah akan terjadi persalinan (Ma'rifah, 2014).

Penelitian ini sesuai dengan hasil penelitian Lestari, dkk terdapat perbedaan (adanya penurunan) tingkat nyeri sebelum dan sesudah pemberian deep back massage ${ }^{1}$. Penelitian Wulandari, dkk yang menyatakan hasil massage effleurage pada ibu primigravida kala I fase aktif memberikan pengaruh terhadap pengurangan tingkat nyeri persalinan. Tidak adanya pengaruh deep back massage hal ini karena faktor persepsi atau toleransi terhadap nyeri yang berbeda-beda serta dapat dikarenakan penekanan yang dilakukan saat massage kurang tepat (Wulandari, 2015).

Nyeri yang dirasakan seseorang bersifat personal dan unik, dimana setiap individu berbeda dan tidak dapat disamakan meskipun mempunyai kondisi yang sama (Rohani, 2011).

Penanganan dan pengawasan nyeri persalinan terutama pada kala 1 fase aktif sangat penting, karena ini sebagai titik penentu apakah seorang ibu bersalin dapat menjalani persalinan normal atau diakhiri dengan suatu tindakan dikarenakan adanya penyulit yang diakibatkan nyeri yang sangat hebat (Hermawati., 2009).

Intensitas nyeri dan pembukaan serviks sesudah diberikan intervensi deep back dan rubbing massage

Intensitas nyeri pada kelompok eksperimen sesudah dilakukan intervensi adalah 2.7500 sedangkan pada kelompok kontrol 2.7000. Pembukaan serviks pada kelompok eksperimen sesudah dilakukan intervensi adalah 2.7000 sedangkan pada kelompok kontrol 9.1000 .

Metode deep back dan rubbing massage merupakan salah satu metode pengendalian nyeri berupa pijitan atau massage dengan menekan daerah sakrum dan punggung secara mantap dengan telapak tangan, lepaskan dan tekan lagi, begitu seterusnya. Pasien dalam keadaan berbaring miring, dilakukan selama \pm 20 menit selama kontraksi $( \pm 6$ kali kontraksi).

Dengan melakukan metode deep back dan rubbing massage, memberi rasa rileks sehingga kecemasan ibu berkurang serta ibu dapat mengatasi rasa nyeri pada persalinannya. Hal ini sejalan dengan gate control theory Dasar pemikiran pertama gate control theory adalah bahwa keberadaan dan intensitas pengalaman nyeri tergantung pada transmisi tertentu pada impuls - impuls saraf. Kedua, mekanisme gate atau pintu sepanjang system saraf mengontrol atau mengendalikan transmisi nyeri. Akhirnya, jika gate terbuka, impuls yang menyebabkan sensasi nyeri 
dapat mencapai tingkat kesadaran. Jika gate tertutup, impuls tidak mencapai tingkat kesadaran dan sensasi nyeri tidak dialami. Indikator adanya dan intensitas nyeri yang paling penting adalah laporan ibu tentang nyeri itu sendiri. Namun demikian intensitas nyeri juga dapat ditentukan dengan berbagai macam cara salah satunya adalah dengan menanyakan pada ibu untuk menggambarkan nyeri atau rasa tidak nyamannya (Maryunani, 2010).

Pada analisis bivariat digunakan uji $\mathrm{t}$ tes paired untuk mengetahui ada tidaknya perbedaan intensitas nyeri dan pembukaan

Tabel 2. Hasil Olah Data Analisis Bivariat dengan Uji T Test Paired

\begin{tabular}{ll}
\hline Kelompok & $\mathrm{P}$ \\
\hline $\begin{array}{l}\text { Eksperimen } \\
\text { Kontrol }\end{array}$ & 0,000 \\
\hline
\end{tabular}

Berdasarkan hasil perhitungan uji $t$ diketahui rata - rata kenaikan pada kelompok kontrol sebesar 1.45000 sedangkan rata - rata kenaikan pada kelompok eksperimen sebesar 2.22500, sehingga diketahui bahwa kenaikan di kelompok kontrol lebih besar dari pada kelompok eksperimen. Diketahui juga dari nilai t hitung sebesar 7,660 dan nilai sig 0,000 . Jadi dapat disimpulkan bahwa nilai sig. kurang dari $0,05(p=0,000<0,05)$, sehingga dapat dinyatakan terdapat perbedaan yang signifikan dalam penurunan intensitas nyeri dan pembukaan serviks pada kelompok eksperimen.

Pengaruh pemberian deep back dan rubbing massage terhadap intensitas nyeri dan pem- serviks pada kelompok eksperimen (yang diberi perlakuan) dan kelompok kontrol. Kesimpulan penelitian dinyatakan signifikan apabila signifikan apabila $\mathrm{t}$ hitung $>\mathrm{t}$ tabel pada taraf signifikansi $5 \%$ dan nilai $\mathrm{p}$ $<0,05$. Berikut merupakan ringkasan hasil uji $\mathrm{t}$ tes paired pada kelompok eksperimen (yang diberi perlakuan deep back dan rubbing massage) dan kelompok kontrol.

\section{bukaan serviks pada ibu bersalin di BPM Ka- bupaten Sleman}

Berdasarkan hasil perhitungan uji $\mathrm{t}$ diketahui rata - rata kenaikan pada kelompok kontrol sebesar 1.45000 sedangkan rata - rata kenaikan pada kelompok eksperimen sebesar 2.22500, sehingga diketahui bahwa kenaikan di kelompok kontrol lebih besar dari pada kelompok eksperimen. Diketahui juga dari nilai t hitung sebesar 7,660 dan nilai sig 0,000 . Jadi dapat disimpulkan bahwa nilai sig. kurang dari 0,05 $(p=0,000<0,05)$, sehingga dapat dinyatakan terdapat perbedaan yang signifikan dalam penurunan intensitas nyeri dan pembukaan serviks pada kelompok eksperimen.

Nyeri persalinan adalah salah satu rasa sakit yang paling parah pada manusia di se- 
luruh dunia, terlepas dari perbedaan perasaan individu (Akbarzadeh M., Masoudi Z., Hadianfard M.J., 2014).

Menurut penelitian Maita menyatakan bahwa nyeri pada persalinan kala I bisa diatasi dengan deep back massage. Dari hasil penelitian diketahui bahwa dari 13 responden yang merasakan nyeri (skor 6-10) sebelum deep back massage mengalami penurunan nyeri (skor 0-4) sesudah deep back massagee sebanyak $9(42,9 \%)$ responden sedangkan ibu yang mengalami nyeri (skor 6-10) sebelum deep back massage tidak mengalami penurunan nyeri (skor 6-10) setelah dilakukan deep back massage sebanyak 4 (19\%) responden. Hal ini menggambarkan penurunan rasa nyeri persalinan ibu. Berdasarkan uji statistik didapatkan nilai $p$-value adalah 0,004 $(p<0,05)$. Adanya penurunan nyeri ini disebabkan kondisi ibu yang dapat mengendalikan stress, ibu yang bersikap tenang dan percaya bahwa ia dapat mengendalikan nyeri tersebut (Maita., 2016).

Menurut penelitian Nafiah Nyeri pada persalinan kala I fase aktif sebelum dilakukan metode deep back massage di Klinik Pratama Mutiara Bunda Kawalu Kota Tasikmalaya berada pada nyeri berat terkontrol dengan nilai rata- rata 7,97, setelah dilakukan metode deep back massage berada pada nyeri sedang dengan nilai rata-rata 5. Terdapat pengaruh metode deep back massage terhadap nyeri pasa persalinan kala I fase aktif di Klinik Pratama Mutiara Bunda Kawalu Kota Tasikmalaya dengan nilai $(\rho=0,001)$.
Hal ini sesuai dengan penelitian Nurulicha (2019) dengan judul Pengaruh Deep Back Massage Terhadap Tingkat Nyeri Pada Ibu Bersalin Kala I Fase Aktif Di Klinik Bersalin Siti Khodijah Jakarta Selatan Tahun 2019 bahwa nyeri yang dirasakan ibu bersalin kala I fase aktif mengalami penurunan setelah diberikan Deep Back Massage. Sebelum dilakukan Deep Back Massage ibu bersalin kala I fase aktif mengalami nyeri berat terkontrol sesudah di berikan Deep Back massage menjadi nyeri ringan (Nurulicha., 2019).

\section{Kesimpulan}

Berdasarkan hasil perhitungan uji $t$ diketahui rata - rata kenaikan pada kelompok kontrol sebesar 1.45000 sedangkan rata - rata kenaikan pada kelompok eksperimen sebesar 2.22500, sehingga diketahui bahwa kenaikan di kelompok kontrol lebih besar dari pada kelompok eksperimen. Diketahui juga dari nilai t hitung sebesar 7,660 dan nilai sig 0,000 . Jadi dapat disimpulkan bahwa nilai sig. kurang dari $0,05(p=0,000<0,05)$, sehingga dapat dinyatakan terdapat perbedaan yang signifikan dalam penurunan intensitas nyeri dan pembukaan serviks pada kelompok eksperimen.

Dari penelitian ini diperoleh kesimpulan bahwa metode deep back dan rubbing massage memiliki pengaruh terhadap intensitas nyeri dan pembukaan serviks pada ibu hamil, dimana ibu hamil yang melakukan intervensi ini, intensitas nyeri akan menurun dan pembukaan serviks akan cepat. 


\section{Daftar Pustaka}

Akbarzadeh M., Masoudi Z., Hadianfard M.J., E. al. (2014). Comparison of the Effects of Maternal Suportif Care and Acupressure (BL32 acupoint) on Pregnant Women's Pain Intensity and Delivery Outcome. J.Pregnancy Vol 2014: 129208 EGC.

Anggraeni, M. (2015). Gambaran Massage terhadap Pengurangan Rasa Nyeri Persalinan Kala I Fase Aktif di BPM NY. Yenie Ika Sugiarti, S. ST. Bakalan Gondang Mojokerto. Skripsi.

Aryani, Yeni., Masrul, \& Evareny, L. (2015). Pengaruh Masasse pada Punggung Terhadap Intensitas Nyeri Kala I Fase Laten Persalinan Normal Melalui Peningkatan Kadar Endorfin. Jurnal Kesehatan Andalas.

Dahlan, S. M. (2013). Besar Sampel dan Cara Pengambilan Sampel. Jakarta: Salemba Medika.

Fitrianingsih. (2017). Perbedaan Metode Deep Back Massage Dan Metode Endorphin Massage Terhadap Intensitas Nyeri Persalinan Kala I Fase Aktif Di Puskesmas Poned Plered Kabupaten Cirebon Tahun 2017. Jurnal Care, 5(3).

Gaidaka. (2017). Pengaruh Deep Back Massage Terhadap Nyeri Persalinan Kala I Fase Aktif lbu Inpartu Primigravida Di BPS Endang Adji, Amd.Keb. Journal Article Jurnal Keperawatan STIKES William Booth.

Hermawati. (2009). Hubungan antara kecemasan pada kehamilan akhir triwulan tiga dengan lama persalinan pada ibu yang melahirkan anak pertama. Anima: Media Psikologi Indonesia, IX(34), Hal; 63-82).

Judha, Sudarti, F. (2012). Teori Pengukuran Nyeri dan Nyeri Persalinan. Yogyakarta: Nuha Medika.

Lestari, D. (2012). Pengaruh Deep Back Massage Terhadap Penurunan Nyeri Persalinan Kala I Fase Aktif Dan Kecepatan Pembukaan Pada Ibu Bersalin Primigravida di Wilayah Kerja BPS Puskesmas Delanggu Kabupaten Mojokerto. The Indonesion Journal of Pulblik Health, 9(1), 37-50.

Ma'rifah, A. R. \& S. (2014). Efektifitas Teknik Counter Pressure dan Endorphin Massage Terhadap Nyeri Persalinan Kala I di RSUD Ajibarang kota Banyumas. Jurnal Unimus. Retrieved from jurnal.unimus.ac.id/index.php/psn12012 010/article/view/1255/1308. Diperoleh tanggal 19 Januari 2017

Maita. (2016). Pengaruh Deep Back Massage Terhadap Penurunan Nyeri Persalinan di BPM Khairani Asnita. Jurnal IImu Kesehatan., 9(2), Hal 186-190.

Marmi. (2012). Intranatal Care Asuhan Kebidanan Pada Persalinan. Yogyakarta: Pustaka Pelajar.

Maryunani, A. (2010). Nyeri dalam Persalinan Teknik dan Cara Penanggulangannya. Jakarta: TIM.

Nurulicha. (2019). Pengaruh Deep Back Massage Terhadap Tingkat Nyeri Pada Ibu Bersalin Kala I Fase Aktif Di Klinik Bersalin Siti Khodijah Jakarta Selatan Tahun 2019. 
Jurnal IImiah Kesehatan Dan Kebidanan, $8(2)$.

Rohani, D. (2011). Asuhan Kebidanan Pada Masa Persalinan. Jakarta: Salemba Medika.

Subaris, H. (2012). Teknik Sampling Untuk Penelitian Kesehatan. Yogyakarta: Graha ilmu.

Suriani. (2019). Pengaruh Teknik Massage Back-Effleurage Terhadap Pengurangan Rasa Nyeri Persalinan Kala I Di Klinik Bersalin Kurnia Kecamatan Delitua Kabupaten Deli Serdang. Jurnal Penelitian
Keperawatanmedik. May -October 2019., 2(1).

Susanti. (2019). Efektifitas Deep Back Massage dan Counterpressure Massage terhadap Intensitas Nyeri Persalinan Kala I Fase Aktif Di Pmb Yusnimar Kota Pekanbaru Tahun 2019. Jurnal Ibu Dan Anak. Mei 2019., 7(1).

Wulandari, D. (2015). Pengaruh Massage Effleurage Terhadap Pengurangan Tingkat Nyeri Persalinan Kala 1 Fase Aktif pada PrimiGravida di Ruang Bougenville RSUD Tugurejo Semarang, (Online). 